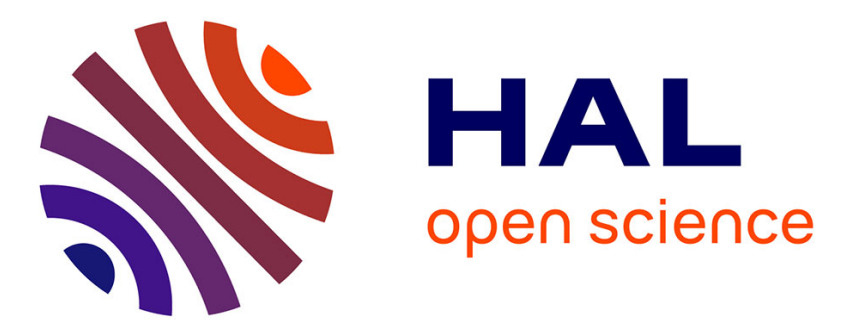

\title{
Impact of Business Intelligence on Firm's Performance in Cameroon
}

Varelle Fossi Maffock, Samuel Fosso Wamba, Jean Robert Kala Kamdjoug

\section{To cite this version:}

Varelle Fossi Maffock, Samuel Fosso Wamba, Jean Robert Kala Kamdjoug. Impact of Business Intelligence on Firm's Performance in Cameroon. International Working Conference on Transfer and Diffusion of IT (TDIT), Jun 2019, Accra, Ghana. pp.227-233, 10.1007/978-3-030-20671-0_16 . hal02294716

\section{HAL Id: hal-02294716 \\ https://hal.inria.fr/hal-02294716}

Submitted on 23 Sep 2019

HAL is a multi-disciplinary open access archive for the deposit and dissemination of scientific research documents, whether they are published or not. The documents may come from teaching and research institutions in France or abroad, or from public or private research centers.
L'archive ouverte pluridisciplinaire HAL, est destinée au dépôt et à la diffusion de documents scientifiques de niveau recherche, publiés ou non, émanant des établissements d'enseignement et de recherche français ou étrangers, des laboratoires publics ou privés. 


\title{
Impact of Business Intelligence on Firm's Performance in Cameroon
}

\author{
FOSSI MAFFOCK Varelle \\ Catholic University of Central Africa, fossivarelle@gmail.com \\ Pr. FOSSO WAMBA Samuel \\ Toulouse Business School, France, s.fosso-wamba@tbs-education.fr \\ Pr. KALA KAMDJOUG Jean Robert \\ Catholic University of Central Africa, jrkala@gmail.com
}

\begin{abstract}
.
Globally, virtually all companies pursue the same goals, which range from increasing revenues and attracting new customers to nurturing a good image, while using the least possible resources. To achieve those goals, many available IT (information technologies) tools and systems have to be used to make the process easier. "Information systems and IT become the metaphors that provide different tools and techniques to the businesses that intend to overcome the challenge of these environments". One of those systems or tools is Business Intelligence (BI). What are the prerequisites to the adoption of BI tools by a given company? What are the significant values that prove that BI leads better performance? To answer to these questions, we have decided to investigate the impact of BI on firm's performance in the Cameroonian context. Our research model is built on the TAM (Technology Acceptance Model), the Extended TAM and the IS Success Model. To test and analyze our proposed model, we used a mixed research method.
\end{abstract}

Keywords: Business Intelligence, Enterprise Performance, TAM, IS Success Model.

\section{Introduction}

The term Business Intelligence (BI) refers to technologies, applications and practices for the collection, integration, analysis and presentation of business information. BI includes a variety of tools, applications and methodologies that enable organizations to collect data from internal and external sources; prepare it for analysis; develop and run queries against such data; and create visual supports to make the analytical results available to corporate decision-makers and operational workers. BI is defined as "a combination of processes, policies, culture and technologies for gathering, manipulating, storing and analyzing data collected, in order to communicate information, create knowledge, and inform decision making"[3]. 
As Golfareli and Rizzi (2009) put it, "The potential benefits of business intelligence are accelerating and improving decision-making, optimizing internal business processes, increasing operational efficiency, driving new revenues and gaining competitive advantage over business rivals." Thanks to BI systems, companies can easily identify market trends and spot various business challenges, they said. For [3], "BI helps report business performance, uncover new business decisions regarding competitors, suppliers, customers, financial issues, strategic issues, products and services". And Regarding the adoption of this technology, these authors estimate that BI is implemented by $80 \%$ of U.S. companies in the U.S.A. and by $50 \%$ of European firms. Out of these BI adopters, $89 \%$ of them believe that they might lose their market if they don't adopt BI [4]. Cameroonian companies have been following this global trend as an increasing number of them are adopting BI tools for improved performance; they include mobile service providers MTN Cameroon and Orange Cameroun, as well as Jumia or AfikMarket for e-commerce.

Generally, the $\mathrm{BI}$ is marginally used by organizations in Cameroon economic context. But, we can notice that there is effective used of BI by Cameroonian branches of Foreign Companies like Orange, MTN, Jumia or AfrikMarket.

Yet, a number of impediments to adopting BI tools exist, including their heavy cost and the ambiguity about how the adoption of BI impacts firm performance [5-9]. Under such circumstances, a company planning to adopt BI should fully grasp the advantages and significant value added of BI adoption. There is a wide range of studies on Bl's impact on enterprise's performance worldwide [7, 8]. However, the Cameroonian context is still under investigation and there remains a long way to go; and this explains the significance this study on the "Impact of business intelligence on company's performance" in Cameroun. The purposes of this study is to show how BI adoption in an enterprise could lead it to a better performance and also to serve as example to others in this economic context. As a reminder, the following research questions will be answered herein:

- How does BI impact on enterprise performance?

- What are the key drivers of BI leading to increased enterprise performance?

\section{Conceptual Model and Hypotheses}

For this study, the hypothesized variables and their relationships in the model are being derived from the available literature, and the model is being drawn on TAM, Extended TAM and IS success Model. We combine these models to catch entirely BI success in both individual and organisational level. And variables, from these models, will helps use to have a better measure of firm's performances. Our different constructs and hypotheses are as follows: 


\section{Core constructs}

Subjectives Norms: A person's perception that most people who are important to him/her think he/she should or should not perform the behavior in question.[10]

H1: Subjective Norms will impact on image.

H2: Subjective Norms will impact on Perceived Usefulness.

Image: The degree to which the use of BI is perceived as being able to enhance one's status in one's social system[11].

H3: Image will have positive effects on Perceived Usefulness.

Output Quality: Is about how BI will impact one's ability to well perform a job.[11]

H4: Output Quality has a positive impact on Perceived Usefulness.

Result Demonstration: is about how easy is to show the benefits of accepting BI.[10]

H5: Result Demonstration will have positive effects on Perceived Usefulness.

Job Relevance: the adequate application of BI in the job to do.[11]

H6: Job Relevance will have positive effects on Perceived Usefulness.

Perceived usefulness of BI: is "the degree to which a person believes that using a BI system would enhance his or her job performance" [12].

H11: Perceived Usefulness will significantly impact the Attitude Toward Using BI

H14: Perceived Usefulness will significantly impact the Intension to Use BI.

Perceived ease of use: is defined as "the degree to which a person believes that using a particular system would be free of effort" [12].

H12: Perceived ease of use will positively impact Perceived Usefulness of BI

H10: Perceived ease of use will positively impact the Attitude Toward Using BI.

Service Quality: Service quality refers to through the following attributes: tangible, reliability, responsiveness, assurance, functionality, interactivity, and empathy [13-15].

H20: Service quality will impact the Intension to Use BI.

H21: Service quality will impact the Satisfaction.

System Quality: it is "concerned with whether or not there are bugs in the systems, the consistency of the user interface, ease of use, response rate in interactive systems, documentation, and, sometimes quality and maintainability of the of the program code" [16].

H17: System Quality will impact the Intension to Use.

H19: System Quality will impact the Satisfaction.

Information quality: it is "concerned with such issue as timeliness, accuracy, relevance, and format of information generated by BI" [16].

H16: Information Quality will impact the Intension to Use.

H18: Information Quality will impact the Satisfaction.

Attitude toward using BI: evaluation of an attitudinal object either representing a positive or negative valence $[10,17-18,28-31]$. 
H15: The Attitude Toward Using BI will have a direct positive impact on the Intention to Use

Intention to use BI: It is "the degree and manner in which employees utilize the capabilities of an e-government system" [19].

H23: Intention to Use will have direct positive effect on Use.

Satisfaction: it is defined as the "system user's satisfaction with regard to system speed, number of functions, quality and format" [20].

H22: Satisfaction will impact positively Job Satisfaction and Intension to Use.

Use of BI: it examines the actual use of BI, the extent of use of BI in the users' work, and the number of system applications used in the users' work [21].

H24: The Use of BI will impact the Satisfaction.

H30: The Use of BI will impact the Job Satisfaction.

Job satisfaction: it is concerned with examining the successful interaction between BI and its users[22].

H26: Job Satisfaction will positively impact the Satisfaction.

H27: Job Satisfaction will positively impact the Job Performance.

Job Performance: it examines the impact of IS on the users' performance [21].

H28: Job Performance will have a positive direct impact on Financial Performance.

H29: Job Performance will have a positive direct impact on Market Performance.

Financial performance: it is concerned with Customer retention, Sales growth, Profitability, and Return on investment.[5]

Market performance: it refers to the entering of new markets, the introduction of new products or services more quickly than competitors, and to the implementation of the best success rate for new products or services and market shares.[5]

\section{Moderating constructs}

Experience: is define as previous contact or easy use of IS technologies[11]

H7, H8: "The direct effect of Subjective norm on intentions may subside over time increased system experience" [11].

Voluntariness: "extend to which potential adopters perceive the adoption decision to be non-mandatory" [11]

H9: Voluntariness will significantly impact the relationship between Subjective Norms and the Intention to Use.

Our proposed research model for this study adapted from IS Success Model[23], TAM model[24, 25] and extended TAM [11] is being designed as follows: 
Fig. 1. Research model

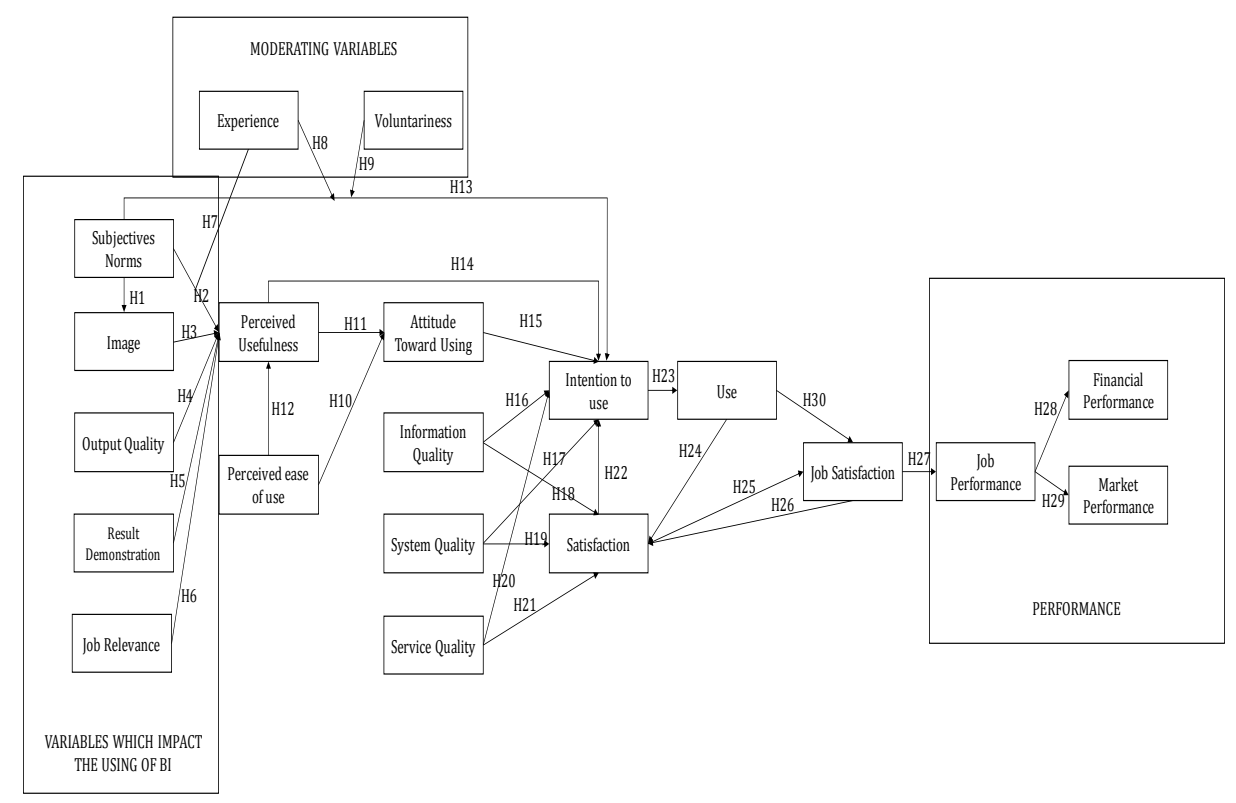

Methodology

A mixed methods research is used in this paper to test and analyze the adopted model research. [11, 26] defined the mixed methods research as a method combining quantitative and qualitative conceptions in the same research study, and which is developed in response to the observed limitations of such conceptions. For our model, we started with a quantitative study, which was followed by a qualitative study in order to better understand and justify result of the quantitative research. This study was carried out in an enterprise that used BI tools like MTN Orange Jumia AfrikMarket. The first step of the study will consist on conducting multiples interviews to obtain viewpoints about BI and Cameroonian Enterprise performance; this will be follow by a pre-test phase, and after with a pilot study and will proceed with collect of data in those enterprise by using Google forms. This approach is recommended by Frippiat and Marquis [27]. Its main advantages are twofold: (1) the possible to surpass the geographical constraints and (2) the wider follow-up of BI development. Our structural research model will be tested with SmartPLS 3.2.7 software. 


\section{Expected Contribution}

This research is expected to help understand the impact of Business Intelligence on Companies performance in the Cameroonian environment. The purposes of this study is to show how BI adoption in Cameroon economic context could lead firms to a better performance and serve as example for others in the same economic context. To achieve our goal (give answer to all our questions), we used a mixed research method to allow a better contribution to the existing literature on Business Intelligence and Enterprise Performance.

While this study is just at the step of reviewing literature, it harbors some limits. Firstly, as the study was conducted in the Cameroonian context, there is some geographical limitation, coupled with the fact that the country has few companies that are already implementing BI tools. As a result, it will be difficult for us to collect data. Secondly, given the magnitude of our proposed research, the target population may not give objective answers to questions (in our forms), which could distort our final results. Lastly, studies about BI and Firm's performance in Cameroon and surrounding countries remain inadequate in terms of number. In order to remediate with that, we will carry a complementary qualitative study which can be a case of study on one of those companies which use BI in Cameroon.

\section{References}

1. Bedell-Pearce, J., Safe digital transformation for SMEs. Network Security, 2018. 2018(11): p. 6-7.

2. Sharda, R., D. Delen, and E. Turban, Business intelligence, analytics, and data science: A managerial perspective Saddle River, NJ: Pearson-Prentice Hall, 2016.

3. Foley, E. and M.G. Guillemette, What is Business Intelligence? . International Journal of Business Intelligence Research, 2010. 1(4): p. 1-28.

4. Columbus, L., $84 \%$ of enterprises see big data analytics changing their industries competitive landscapes in the next year. Forbes, 2014.

5. Akter, S., et al., How to improve firm performance using big data analytics capability and business strategy alignment? International Journal of Production Economics, 2016: p. 113-131.

6. Ramanathan, R., et al., Adoption of business analytics and impact on performance: A qualitative study in retail. Production Planning and Control, 2017. 28(11-12): p. 985-998.

7. Sharma, R., S. Mithas, and A. Kankanhalli, Transforming decision-making processes: A research agenda for understanding the impact of business analytics on organizations. European Journal of Information Systems, 2014. 23(4): p. 433-441. 
8. Trailor, M., et al., Perception, reality, and the adoption of business analytics: Evidence from North American professional sport organizations. Omega, 2016. 59: p. $72-83$.

9. Yeoh, W. and A. Popovic, Extending the Understandng of Critical Success Factors for Implementing Business Intelligence Systems International Funders for Indigenous Peoples, 2018.

10. Ajzen, I. and M. Fishbein, Understanding attitudes and predicting social behavior. Englewood Cliff s, NJ: Prentice Hall, 1980.

11. Venkatesh, V. and F.D. Davis, A theoretical extension of the technology acceptance model: Four longitudinal field studies. Management Science, 2000. 46(2): p. 186204.

12. Davis, F.D., R.P. Bagozzi, and P.R. Warshaw, Extrinsic and intrinsic motivation to use computers in the workplace. Journal of Applied Social Psychology, 1992. 22(14): p. 1111-1132.

13. DeLone, W.H. and E.R. Mclean, The DeLone and McLean Model of Information Systems Success: A TenYear Update. Journal of Management Information Systems / Spring, 2003. 19(4): p. 9-30.

14. Lin, F., S.S. Fofanah, and D. Liang, Assessing citizen adoption of e-Government initiatives in Gambia: A validation of the technology acceptance model in information systems success. Government Information Quarterly, 2011. 28(2): p. 271-279.

15. Pituch, K.A. and Y. Lee, The influence of system characteristics on e-learning use. Computers \& Education, 2006. 47(1): p. 222-244.

16. Seddon, P.B. and K.Y. Kiew, A Partial Test and Development of the DeLone and McLean's Model of IS Success. Proceeding of the 15th International Conference on Information Systems, Vancouver, Canada, 1994, 1994.

17. Berger, I.E. and A.A. Mitchell, The effect of advertising on attitude accessibility, attitude confidence, and the attitude-behavior relationship. Journal of Consumer Research, 1989. 16(3): p. 269-279.

18. Fazio, R.H., How do attitudes guide behavior? The handbook of motivation and cognition foundations of social behavior 1986: p. 204-243.

19. Petter, S., W. DeLone, and E.R. McLean, Information Systems Success: The Quest for the Independent Variables. Journal of Management Information Systems, 2013. 29(4): p. 7-62.

20. Lin, W.-S. and C.-H. Wang, Antecedences to continued intentions of adopting elearning system in blended learning instruction: A contingency framework based on models of information system success and task technology fit. Computers \& Education, 2012. 58(1): p. 88-99.

21. Doll, W.J. and G. Torkzadeh, The Measurement of End-user Computing Satisfaction. MIS Quarterly, 1988b. 12(2): p. 259-274.

22. Seddon, P. and K. Yip, An Empirical Evaulation of User Information Satisfaction (UIS) Measures for Use with General Ledger Account Software. Journal of Information Systems, 1992: p. 75-92.

23. Delone, W.H. and E.R. Mclean, Information Systems Success: The Quest for the Dependent Variable. Information Systems Research, 1992. 3(1): p. 60-95. 
24. Davis, F.D., Perceived Usefulness, Perceived Ease of Use, and User Acceptance of Information Technology. MIS Quarterly, 1989. 13(3): p. 319- 339.

25. Davis, F.D., P.R. Bagozzi, and W. P., User acceptance of computer technology: A comparison of two theoretical models. Management Science, 1989. 35: p. 982- 1003.

26. D. Caruth, G., Demystifying Mixed Methods Research Design: A Review of the Literature. 2013.

27. Frippiat, D. and N. Marquis, Web Surveys in the Social Sciences: An Overview. Population, 2010. 65(2): p. 309-338.

28. Dwivedi, Y. K., Rana, N. P., Janssen, M., Lal, B., Williams, M. D., \& Clement, M. (2017a). An empirical validation of a unified model of electronic government adoption (UMEGA). Government Information Quarterly, 34(2), 211-230.

29. Dwivedi, Y. K., Rana, N. P., Jeyaraj, A., Clement, M., \& Williams, M. D. (2017b). Re-examining the unified theory of acceptance and use of technology (UTAUT): Towards a revised theoretical model. Information Systems Frontiers, 1-16. DOI: https://doi.org/10.1007/s10796-017-9774-y.

30. Rana, N. P., Dwivedi, Y. K., Lal, B., Williams, M. D. and Clement, M. (2017). Citizens' adoption of an electronic government system: towards a unified view. Information Systems Frontiers, 19(3), 549-568.

31. Rana, N. P., Dwivedi, Y. K., Williams, M. D., \& Weerakkody, V. (2016). Adoption of online public grievance redressal system in India: Toward developing a unified view. Computers in Human Behavior, 59, 265-282. 